\title{
EPISTEMOLOGI KRITIK HADIS
}

\author{
Hedhri Nadhiran \\ Fakultas Ushuluddin dan Pemikiran Islam UIN Raden Fatah \\ hedhrinadhiran_uin@ radenfatah.ac.id
}

\begin{abstract}
Hadith is agreed as the second source of Islamic teachings after the Qur'an. However, in order to make it the basis of doctrine, hadith must pass the test of naqd al-hadis and fiqh al-hadis. Related to naqd al-hadis, the problem that arises is how to make a hadith can be believed or allegedly derived from the Prophet, since the hadith is historical data about past events, in this case the life of the Prophet. What is a measuring tool (method) that can be used to test a hadith until it is believed authenticity comes from the Messenger of Allah. This question arises from the history of the hadith journey narrated by many narrators with diverse characters, the hadith is also 'vulnerable' to fraud and deviation, and its messenger process tends to be ahad, thus making the problem of authenticity of hadith become a very widespread discourse - even since Rasulullah saw, died. To that end, the scholars then formulated a theory that was agreed as a "test stone" of authenticity of hadith. This is then the requirement of the hadith, where the activity of testing is known by the criticism of hadith or naqd al-hadis. By some scholars of hadith, this activity and method is used as a branch of ulumul hadith called the science of hadith criticism or 'ilm naqd al-hadis. This paper will analyze the theory of the hadith out of the aspect of epistemology since in the modern era, the theory of this sovereignty is criticized because it is still considered to have 'weakness' so that the judgment of hadith judgments conducted by the scholars of hadith in the past should be re-examined. Regardless of the pros and cons arising from this assessment, some modern Muslim thinkers offer a new method of criticism that is expected to close that weakness; either by simply reconstructing the criticism of a sanad or by the method of merging the two (criticism of sanad and criticism of matan). It is hoped that through this effort a new method of criticism of the hadith can be given that the accuracy (authenticity) of the authenticity of the hadith reinforces the view that the hadith can be attributed to the Messenger of Allah.
\end{abstract}

Key words: Epistemology, Criticism of Hadith, Sanad, Matan

\begin{abstract}
Abstrak : Hadis disepakati sebagai sumber ajaran Islam kedua setelah al-Qur'an. Namun, untuk dapat menjadikannya sebagai dasar ajaran, hadis harus melewati uji naqd al-hadis dan fiqh al-hadis. Terkait dengan naqd al-hadis, persoalan yang muncul adalah bagaimana menjadikan sebuah hadis dapat diyakini atau diduga kuat berasal dari Nabi saw., mengingat hadis merupakan data sejarah tentang peristiwa masa lalu, dalam hal ini kehidupan Rasulullah. Apa alat ukur (metode) yang dapat dipakai untuk menguji sebuah hadis hingga diyakini keotentikannya berasal dari Rasulullah saw. Pertanyaan ini mengemuka jika melihat sejarah perjalanan hadis yang dinarasikan oleh banyak perawi dengan karakter yang beragam, hadis juga 'rentan' mengalami pemalsuan dan penyimpangan, serta proses periwayatannya yang cenderung bersifat $\mathrm{ahad}$, sehingga menjadikan problem otentisitas hadis menjadi diskursus yang sangat marak - bahkan sejak Rasulullah saw, wafat. Untuk itu, para ulama kemudian merumuskan sebuah teori yang disepakati sebagai "batu uji" otentisitas hadis. Inilah yang kemudian menjadi syarat keshahihan hadis, dimana aktivitas pengujian tersebut dikenal dengan kritik hadis atau naqd al-hadis. Oleh sebahagian ulama hadis, aktivitas dan kaedah ini dijadikan sebagai satu cabang ulumul hadis yang disebut dengan ilmu kritik hadis atau 'ilm naqd al-hadis.
\end{abstract}


Tulisan ini akan menganalisis teori keshahihan hadis dari aspek epistemologi mengingat pada era modern, teori keshahihan ini mendapat kritikan karena dianggap masih memiliki 'kelemahan' sehingga penilaian keshahihan hadis yang dilakukan oleh ulama hadis pada masa lalu harus ditela'ah ulang. Terlepas dari pro-kontra yang timbul karena penilaian ini, beberapa para pemikir muslim modern menawarkan metode kritik baru yang diharapkan dapat menutup kelemahan tersebut; baik dengan hanya merekonstruksi kritik sanad ataupun dengan metode penggabungan keduanya (kritik sanad dan kritik matan). Diharapkan, melalui upaya ini diperoleh metode kritik hadis baru yang mampu memberikan tingkat akurasi (kebenaran) otentisitas hadis yang meneguhkan pandangan bahwa hadis benar-benar dapat dinisbahkan kepada Rasulullah saw.

Kata kunci : Epistemologi, Kritik Hadis, Sanad, Matan 


\section{A. Pendahuluan}

Dalam sejarah keilmuan, filsafat dipandang sebagai ilmu yang pertama kali muncul sehingga disebut sebagai "induk" atau "ibu" ilmu pengetahuan atau mater scientarium. Karena kedudukannya sebagai induk ilmu pengetahuan, ada tiga persoalan besar yang menjadi fokus perhatian filsafat, yaitu (1) Persoalan tentang keberadaan (being) atau eksistensi (existence), yang berhubungan dengan cabang filsafat metafisika; (2) Persoalan tentang pengetahuan (knowledge) atau kebenaran (truth), dimana pengetahuan ditinjau dari segi isinya bersangkutan dengan cabang filsafat epistemologi. Sedangkan kebenaran ditinjau dari segi bentuknya berkenaan dengan cabang filsafat logika. (3) Persoalan nilai (values) yang dapat dibedakan menjadi dua; nilai kebaikan tingkah laku dan nilai keindahan. Cabang filsafat yang lahir dari persoalan ini adalah filsafat etika dan filsafat estetika. (Tim Dosen: 2007, 31).

Epistemologi, sebagai salah satu cabang filsafat yang mempelajari tentang pengetahuan, bermaksud mengkaji dan menemukan ciri-ciri umum dari pengetahuan manusia dengan fokus utama bagaimana pengetahuan itu diperoleh dan diuji kebenarannya, serta sejauh mana ruang lingkup dan batas-batas kemampuan manusia untuk mengetahui. (Idzam Fautanu: 2012, 165). Inilah sesungguhnya makna yang hakiki dari epistemologi. Di samping pemaknaan ini, epistemologi juga kadang dipahami sebagai cara untuk mengetahui dan mendapatkan kebenaran suatu ilmu (pengetahuan ilmiah). Untuk membedakan antara epistemologi sebagai cabang filsafat dengan epistemologi sebagai cara atau metode mendapatkan kebenaran, maka yang pertama dikenal dengan theory of knowledge (teori atau filsafat pengetahuan), sementara yang kedua theory of science (filsafat ilmu). Filsafat ilmu lahir sebagai kelanjutan dari pengembangan filsafat pengetahuan mengingat sifatnya sebagai a higher level of knowledge. Oleh karena itu, perbedaan keduanya terletak pada objeknya, dimana objek material filsafat pengetahuan berupa gejala pengetahuan, sedang objek material filsafat ilmu adalah gejala-gejala ilmu (pengetahuan ilmiah). Berangkat dari perbedaan ini, filsafat ilmu dipahami sebagai penyelidikan filosofis tentang ciri-ciri pengetahuan ilmiah dan cara-cara (metode) untuk memperolehnya. Namun dalam lingkup kerjanya, filsafat ilmu tetap menggunakan tiga komponen penyangga yang menjadi pertanyaan utama induknya, filsafat pengetahuan, yaitu ontologi ilmu yang meliputi hakikat ilmu itu, apa hakikat kebenaran dan kenyataan yang inheren dengan pengetahuan ilmiah; epistemologi ilmu, meliputi sumber, sarana dan tatacara menggunakan sarana tersebut untuk mencapai pengetahuan ilmiah; dan aksiologi ilmu, berkenaan dengan nilai-nilai (values) yang bersifat normatif dalam pemberian makna terhadap kebenaran atau kenyataan (Tim Dosen: 2007, 11-12, 44-46). 
Berangkat dari argumentasi di atas, tulisan ini akan membahas tentang apa dan bagaimana epistemologi yang membentuk kajian kritik hadis. Bahasan tentang persoalan ini menjadi sesuatu yang penting karena banyak ajaran Islam yang direduksi dan atau berasal dari hadis. Ajaran Inilah yang kemudian diamalkan oleh umat Islam sebagai bentuk peneladanan terhadap Rasulullah. Dari argumentasi ini, jika disepakati bahwa sebuah epistemologi akan mempengaruhi cara berfikir masyarakat yang mengadopsinya, maka ketika hadis dipahami dan diamalkan, boleh jadi epistemologi yang membentuk hadis - sedikit banyak, akan berpengaruh terhadap cara berfikir dan bersikap umat Islam. Hal ini diperkuat oleh kondisi umat Islam Indonesia yang sangat menghargai nilai-nilai agamanya. Bahkan bagi mereka, agama dipandang sebagai satu diantara tiga hal yang menjadi bunyah takwin al- 'aqlial-Indonisiyyin (struktur nalar pembentuk orang Indonesia) di samping modernitas dan budaya nenek moyang. Ajaran Islam menjadi GPS (Global Positioning System) bagi umat Islam dalam bertindak melakukan kegiatan sehari-hari mereka (Saifuddin Zuhry: 2016, 178).

\section{B. Epistemologi dalam Wacana Filsafat}

Pada dasarnya, pertanyaan yang timbul dalam persoalan epistemologi bukan mengenai prosedur penyelidikan ilmiah, tetapi dengan mempertanyakan: "mengapa prosedur ini dan bukan yang lain?", Apa jaminannya, bila ada, dan apakah metode ini membuktikan yang lain". Terkait dengan pertanyaan ini, Jujun S. Suriasumantri menjelaskan bahwa pada hakekatnya, setiap manusia membutuhkan jawaban yang benar dari apa yang ingin diketahui, bukan sekedar jawaban yang bersifat sembarangan. Karena itu masalah yang muncul kemudian adalah bagaimana cara menyusun pengetahuan yang benar? Masalah inilah yang dalam kajian filsafat disebut epistemologi, dan landasan epistemologi ilmu adalah metode ilmiah atau cara yang dilakukan ilmu dalam menyusun pengetahuan yang benar (Jujun S. Suriasumantri: 2007, 105). Adapun yang menjadi menjadi problematika umum epistemologi untuk menjawab permasalahan utama ini adalah tentang hakikat pengetahuan, validitas kebenaran serta sumber dan metode untuk memperoleh pengetahuan.

\section{Hakikat Pengetahuan}

Hakikat pengetahuan adalah persoalan pertama yang menjadi bahasan epistemologi. Berkaitan dengan hal ini, ada dua teori yang menjelaskan persoalan tersebut. Pertama, teori realisme. Teori ini dibangun di atas landasan ontologis bahwa eksistensi suatu benda terletak dalam dirinya sendiri (being is being). Landasan epistemologi ini kemudian melahirkan konsep epistemologi yang memandang hakikat pengetahuan sebagai gambaran atau copy dari apa yang ada dalam alam nyata (Harold A. Titus: 1984, 214). Oleh karena itu, validitas kebenaran suatu gagasan mengenai sesuatu terletak pada apakah gagasan tersebut benar-benar memberi pengetahuan mengenai sesuatu atau 
tidak (Louis O. Kattsof : 1989, 111). Realisme selanjutnya melahirkan objektivisme yang percaya bahwa ada hal-hal yang hanya terdapat didalam dan tentang dirinya sendiri serta yang hakikatnya tidak terpengaruh orang lain. Kedua, teori idealisme. Teori ini dibangun di atas landasan ontologis yang menyatakan bahwa hakikat segala hal terletak pada jiwa atau ide, sehingga jiwa dianggap memiliki kedudukan yang utama dalam alam semesta (Louis O. Kattsof : 1989, 225). Oleh karena itu, akal manusia dalam aliran idealisme memperoleh posisi yang utama. Landasan ontologis ini kemudian melahirkan subjektivisme yang berpendirian bahwa pengetahuan merupakan proses mental atau psikologis yang bersifat subjektif dan karenanya pengetahuan merupakan gambaran subjektif tentang realitas (Imam Syaukani: 2006, 159-160).

\section{Sumber Pengetahuan}

Persoalan epistemologi yang berkaitan dengan sumber dan metode untuk memperoleh pengetahuan melahirkan empat pandangan yang menjadi arus utama (mainstream) pemikiran epistemologi yaitu rasionalisme, empirisme, intuisionalisme dan dialog antara rasionalisme dan empirisme. Pertama, rasionalisme yaitu aliran epistemologi yang berpendirian bahwa sumber pengetahuan terletak pada rasio (Jujun S. Suriasumantri: 2007, 201). Tokoh aliran ini adalah Rene Descartes (1596-1650), yang dianggap sebagai 'bapak filsafat modern dan yang memperkenalkan sikap skeptis (keraguan) sebagai 'warna dasar' bagi epistemologi Barat. Menurut aliran ini, tidak ada kebenaran ilmiah yang dapat dipertanggungjawabkan tanpa mendapatkan pembenaran dari rasio. Rasio mempunyai kemampuan untuk menyingkap kebenaran dengan diri sendiri. Ini bukan berarti rasio mengingkari sepenuhnya peran pengalaman dalam mendapatkan pengetahuan. Pengalaman tetap diakui eksistensinya, hanya saja ia ditempatkan sebatas sebagai sejenis perangsang bagi rasio atau akal, tidak sebagai prosedur dominan dalam menentukan pengetahuan.

Kedua, empirisme. Aliran pemikiran empirisme dirintis oleh Francis Bacon (1561-1626), Thomas Hobbes (1588-1679), John Locke (1632-174), George Berkeley (1685-1753) dan David Hume (1711-1776). Aliran empirisme berpendapat bahwa pengetahuan manusia bukan didapatkan lewat penalaran rasional yang abstrak namun lewat pengalaman yang konkret yang ditangkap oleh indera manusia. Ini dikarenakan segala sesuatu yang ada dalam pikiran (rasio) - sebenarnya- berasal dari pengalaman indrawi, karena otak (rasio) itu pada asalnya kosong, baru melalui pengalaman indrawi, rasio itu terisi (Ilyas Supena dan M. Fauzi: 2001, 61). John Locke - seperti dijelaskan oleh Amsal Bachtiar (2006: 99-100), berpendapat bahwa segala pengetahuan datang dari pengalaman dan tidak lebih dari itu. Akal atau rasio dalam hal ini hanya bersifat pasif pada saat pengetahuan didapatkan. Semula, akal mirip dengan secarik kertas yang tanpa tulisan, bersih tiada noda (tabula rasa). Kemudian ia menerima guratan-guratan yang mula-mula kecil dan sedikit, seterusnya makin 
lama makin besar dan banyak yang datang dari pengalaman. Dengan demikian, objek pengetahuan adalah gagasan atau ide-ide yang timbul karena pengalaman, baik pengalaman lahiriah (sensation) atau karena pengalaman batiniah (reflection). Kedua pengalaman ini saling jalin menjalin. Hanya patut digarisbawahi bahwa pengalaman yang menjadi sumber pengetahuan di kalangan empirisme adalah pengalaman yang bersifat materialitik atau indrawi, bukan pengalaman batin seperti yang diusung oleh aliran intuisionalis (Mujamil Qomar: 2007, 72) .

Ketiga, intuisionalisme. Aliran ini berpendapat bahwa pengetahuan diperoleh melalui pengalaman spiritual yang kemudian terejawantahkan dalam bentuk simbol-simbol subjektif yang bersifat diskursif. Namun demikian, intuisi bukan suatu flash of insight, melainkan suatu usaha mental dan konsentrasi pikiran dan pengalaman batiniah yang diuraikan akal budi seakan-akan mengerti dari luar, bersifat relatif dan tergantung dari sudut pandang yang dipaka (Ilyas Supena dan M. Fauzi: 2001, 61-62). Karakteristik pengetahuan yang didasarkan kepada pendekatan intuitif adalah seluruh anatomi pengetahuan berada dalam kerangka dirinya tanpa implikasi apapun terhadap acuan objektif eksternal yang membutuhkan hubungan eksterior. Artinya, hubungan mengetahui dalam bentuk pengetahuan ini adalah hubungan objektif tanpa campur tangan koneksi dengan objek eksternal (Imam Syaukani: 2006, 161). Pengetahuan intuitif semacam ini sering dijumpai pada orang-orang yang mendalami sufistik atau tasauf, dan disebut dengan ma'rifat. Di Barat, tokoh aliran ini adalah Henri Bergson, Maslow dan Nietzsche. Kalangan Barat sendiri tidak sepakat menerima intuisi sebagai sumber pengetahuan. Ini dikarenakan, menurut Jujun (2007: 53), intuisi bersifat personal dan tidak bisa diramalkan sehingga tidak dapat diandalkan untuk menyusun pengetahuan secara teratur. Alasan lainnya, intuisi merupakan pengalaman batin dan bersifat meta-empirik sehingga dianggap tidak memiliki peranan sama sekali dalam mencapai kebenaran.

Keempat, dialog rasionalisme dan empirisme. Aliran ini muncul sebagai sintesis dari aliran rasionalisme dan empirisme setelah sebelumnya melihat kelebihan dan kelemahan yang terkandung dalam kedua aliran epistemologi tersebut. Dengan langkah dialogis ini, kelebihan keduanya dapat dimaksimalkan sementara kelemahannya diminimalkan. Immanuel Kant dan Karl R. Popper adalah filosof yang menggagas upaya dialog tersebut.

Di samping empat sumber pengetahuan ini, dalam filsafat ilmu dikenal juga sumber pengetahuan yang berasal atau didapat dari orang lain, yaitu otoritas atau kesaksian. Kebenaran otoritas dapat dipercaya jika berasal dari orang yang dapat dipercaya atau dapat diterima kebenarannya. Oleh karena itu otoritas tidak dapat dijadikan sumber pertama dalam pengetahuan dan bahkan dapat berbahaya jika tidak diselidiki secara sempurna (Jujun S. Suriasumantri: 2007, 53). Disinilah persoalan muncul, ketika kebenaran hadis dihadapkan kepada sarjana Barat. Mereka 
meragukan - bahkan menolak otentisitas hadis mengingat sumber pengetahuan ini berasal dari otoritas (kesaksian) para perawi hadis, terutama yang hidup di abad ketiga Hijrah.

\section{Validitas Kebenaran}

Persoalan tentang ada tidaknya kebenaran, tentang apa hakikatnya dan bagaimana mengenali, menilai, menguji dan menjaminnya merupakan salah satu masalah pokok dalam epistemologi sejak awal sejarahnya. Terkait dengan cara dan tolok ukur penilaian serta penjaminan kebenaran atau menentukan validitas sebuah pernyataan, para filosof bersandar pada teori uji kebenaran. Pengujian ini dilakukan karena sebuah teori kebenaran bukan hanya memuat pengertian istilah kebenaran, tetapi juga menetapkan syarat-syarat yang perlu dipenuhi agar suatu pernyataan atau kepercayaan dapat disebut benar. Dengan kata lain, di dalamnya juga termuat tolok ukur untuk bagaimana mengenalinya. Berkenaan dengan logis-proposional, secara umum dapat dikatakan bahwa suatu pernyataan itu benar kalau: (1) kita tahu apa arti pernyataan itu, (2) kita tahu bagaimana menguji kebenarannya, (3) kita mempunyai bukti yang cukup memadai untuk mempercayai atau menerimanya. Kalau ketiga syarat itu tidak terpenuhi, maka akan terasa aneh untuk menyatakan bahwa pernyataan itu benar atau salah (J. Sudarminta: 2006, 129).

Dalam sejarah filsafat, secara klasikal terdapat tiga teori kebenaran yang sudah sangat populer untuk menguji dan berupaya menjawab pertanyaan tentang kebenaran secara filosofis, yakni (1) teori kebenaran korespondensi atau kesesuaian, (2) teori kebenaran koherensi atau keteguhan, dan (3) teori kebenaran pragmatis. Namun, di samping ketiga teori kebenaran tersebut, dalam konteks kontemporer dikenal juga dua teori kebenaran lain, yaitu (4) teori kebenaran performatif, dan (5) teori kebenaran konsensus (Jujun S. Suriasumantri: 2007, 53; Zaprulkhan: 2016, 106-107).

\section{a. Teori Kebenaran Korespondensi}

Teori kebenaran korespondensi merupakan teori kebenaran yang paling populer dan sekaligus tertua (Sony Keraf dan Mikhael Dua: 2001, 66). Teori ini menyatakan kebenaran suatu pernyataan terjadi jika isi pengetahuan yang terkandung dalam pernyataan tersebut berkorespondensi (sesuai) dengan objek atau fakta yang dirujuk oleh pernyataan tersebut. Prinsip teori inilah yang dimaksud ketika Paul Churcland - seperti dikutip oleh Zaprulkhan (2016: 107) - menyatakan: "The way in which we can judge our beliefs is by testing them in experience". Suatu cara dimana kepercayaan-kepercayaan kita diuji dengan pengalaman. Jadi, penyelidikan empiris terhadap faktafakta yang dinyatakan dalam suatu proposisi menjadi alat yang objektif untuk menguji kebenaran suatu pernyataan. Dalam konteks inilah, teori korespondensi menempatkan kesetiaan terhadap realitas objektif-faktual (fidelity to objective reality). Dengan kata lain, suatu pernyataan dianggap 
benar apabila terdapat fakta-fakta empiris yang mendukung pernyataan itu. Kebenaran adalah kesesuaian (korespondensi) antara pernyataan tentang sebuah fakta dengan fakta itu sendiri.

\section{b. Teori Kebenaran Koherensi}

Teori kebenaran koherensi banyak dianut oleh kaum rasionalis, seperti Leibniz, Spinoza, Descartes, dan Hegel. Menurut teori ini, kebenaran hanya diperoleh dari kesesuaian (koheren) antara suatu proposisi dengan proposisi yang sudah ada. Maksudnya, tolok ukur kebenaran suatu pernyataan adalah bila pernyataan tersebut sesuai dengan pernyataan lain yang memiliki hierarki lebih tinggi dan telah dianggap benar, yang masih berada dalam jaringan komprehensif dari pernyataan-pernyataan yang berhubungan secara logis. Jadi, yang dimaksud dengan koheren disini adalah saling berhubungan secara sistemik (the truth is systemic coherent). Atas dasar ini, teori koherensi menolak banyak ide yang tidak masuk akal (absurd) dan menganggap beberapa pengalaman sebagai ilusi atau persepsi yang salah, mekipun tidak berarti bahwa ia menolak idea atau kebenaran baru tanpa penyelidikan.

\section{c. Teori Kebenaran Pragmatisme}

Pragmatisme berasal dari bahasa Yunani, pragma, artinya yang dikerjakan, yang dilakukan, perbuatan, dan sebutan bagi aliran filsafat yang dikembangkan oleh William James di Amerika Serikat. Menurut teori ini, kebenaran suatu pernyataan diukur dengan kriteria apakah pernyataan tersebut bersifat fungsional dalam kehidupan praktis atau tidak. Karena itu, bagi kaum pragmatis, validitas kebenaran terletak pada manfaat (utility), kemungkinan dikerjakan (workability) dan akibat yang memuaskan (satisfactory result) (Ilyas Supena dan M Fauzi: 2001, 68: Amtsal Bachtiar: 2006, 119). William James mengembangkan teori pragmatisnya tentang kebenaran dengan berangkat dari pemikirannya tentang 'berpikir'. Menurutnya, fungsi dari berpikir bukan untuk menangkap kenyataan tertentu, melainkan untuk membentuk ide tertentu demi memuaskan kebutuhan atau kepentingan manusia. Karena itu, ide yang benar adalah idea atau teori yang berguna dan dapat berfungsi memenuhi tuntutan dan kebutuhan manusia. Sebaiknya, jika tidak dapat memenuhi kebutuhan, maka ide tersebut dianggap sebagai ide yang salah (Sony Keraf dan Mikhael Dua: 2001, 71).

Pada dasarnya, teori kebenaran pragmatis dibangun untuk menjembatani kelemahan teori korespondensi dan teori koherensi karena argumentasi yang dikemukakan oleh kedua teori tersebut tidak menghasilkan kebenaran yang bersifat absolut sehingga proses pembuktian dalam ilmu juga tidak bersifat absolut. Pluralitas pemikiran yang diproduksi teori koherensi dan relativisme fakta yang dikumpulkan teori korespondensi menyebabkan kebenaran ilmiah juga bersifat relatif karena ia hanya bisa diterima selama tidak terdapat fakta lain yang menolak kebenaran tersebut dan hal ini 
membawa dimensi baru kepada hakikat ilmu yakni bersifat pragmatic. Artinya, ilmu bukan untuk mencari kebenaran absolut, melainkan kebenaran yang bermanfaat bagi manusia dalam tahap perkembangan tertentu (Imam Syaukani: 2006, 164).

\section{d. Teori Kebenaran Performatif}

Menurut J. Sudarminta (2006, 129), teori kebenaran performatif adalah teori yang menegaskan bahwa suatu pernyataan itu benar apabila apa yang dinyatakan itu sungguh terjadi ketika pernyataan itu dilakukan (performed). Misalnya, ketika seorang pejabat resmi Mendagri atas nama Pemerintah menyatakan: "Dengan ini saya melantik anda sebagai Gubernur Jawa Barat”, maka pernyataan itu benar dan memang mengerjakan apa yang dinyatakan. Akan tetapi, pernyataan itu menjadi tidak benar kalau diucapkan oleh orang yang sama sekali tidak punya kewenangan untuk membuat pernyataan tersebut. Dengan kata lain, dalam teori ini sesuatu dianggap benar apabila dinyatakan atau diputuskan oleh pemegang otoritas tertentu. Berbeda dengan penjelasan di atas, A. Sony Keraf (2001: 74) menegaskan bahwa dalam teori ini, suatu pernyataan dianggap benar jika pernyataan itu menciptakan realitas. Jadi, pernyataan yang benar bukanlah pernyataan yang mengungkapkan realitas atau sesuai dengan realitas, tapi justru dengan pernyataan itu tercipta sebuah realitas sesuai dengan pernyataan tersebut.

\section{e. Teori Kebenaran Konsensus}

Adapun teori kebenaran konsensus, pertama kali dikemukakan oleh Thomas Kuhn dan kemudian secara khusus dikembangkan oleh Jurgen Habermas. Menurut teori ini, sebuah pernyataan atau teori dianggap benar kalau diakui atau didukung oleh komunitas ilmuwan bidang yang bersangkutan sebagai benar. Hal ini seperti ditegaskan oleh Kuhn, there is no standard higher than the assent of the relevant community (J. Sudarminta: 2006, 130). Jadi, sesuatu dianggap benar apabila telah diterima oleh kelompok ahli yang relevan dengan keilmuan yang terkait dalam pernyataan tersebut.

Inilah lima teori dasar dalam menguji kebenaran sebuah Berangkat dari tiga pertanyaan mendasar dalam epistemologi ini, dapat ditegaskan bahwa masalah utama dari epistemologi adalah bagaimana cara memperoleh pengetahuan. Pertanyaan tentang 'bagaimana' ini terkait dengan metode-metode yang harus ditempuh untuk mendapatkan sebuah pengetahuan. Dengan kata lain, bahasan utama epistemologi adalah tentang metodologi, yang dapat dimaknai dengan ilmu tentang metode atau ilmu yang mempelajari prosedur atau tata cara mengetahui sesuatu. Jika metode merupakan prosedur atau cara mengetahui sesuatu (memahami objek), maka metodologilah yang mengkerangkai secara konseptual terhadap prosedur tersebut. 


\section{Diskursus Epistemologi Kritik Hadis}

Islam sebagai agama, diyakini bersifat tunggal karena ia lahir dari Yang Maha Tunggal. Namun, ketika masuk ke dalam ranah pemahaman manusia, Islam tidak lagi tunggal. Islam mulai beragam. Pada ranah ini, Islam mulai terpilah menjadi Islam ideal dan Islam historis. Islam ideal bersifat abstrak dan hanya berada di haribaan Tuhan dan Nabi Muhammad, sedang Islam historis adalah Islam yang berada di haribaan manusia. Pada Islam historis inilah muncul istilah fiqh, tasawuf, kalam dan tasawuf, serta melahirkan pelbagai mazhab, aliran dan organisasi keagamaan yang semakin meneguhan keragaman Islam. Tentu saja, ragam Islam historis ini merupakan konsekuensi dari ragam epistemologi yang mendasarinya, karena epistemologi menjadi landasan dasar bagi pijakan ilmu pengetahuan.

Menurut Aksin Wijaya (2014: 1-2), ragam epistemologi Islam itu merupakan akibat perkembangan revolusioner epistemologi Islam itu sendiri, yang terjadi dalam ranah historis; baik menyangkut disiplin keilmuan fiqh, kalam, tasawuf, maupun filsafat. Dalam disiplin keilmuan fiqh melibatkan empat mazhab utama sunni; Hanafi, Maliki, Syafi'i dan Hambali. Di bidang kalam melibatkan dua aliran besar, Mu'tazilah dan Asy'ariyah. Dalam keilmuan tasawuf melibatkan tasawuf falsafi al-Hallaj dan tasawuf syar'i al-Ghazali; dan dalam disiplin keilmuan filsafat melibatkan filsafat paripatetik-emanasionis al-Kindi, al-Farabi, dan Ibnu Sina, filsafat paripatetikteleologis Ibn Rusyd, Filsafat iluminasi Suhrawardi, dan filsafat transendental Mulla Shadra.

Persoalan yang muncul kemudian adalah jika epistemologi Islam klasik sudah berkembang sedemikian rupa dan menghasilkan banyak ilmu, mengapa pada aspek dunia nyata, dikatakan mengalami kemunduran. Apakah kondisi ini hanya karena epistemologi Islam hanya fokus pada persoalan metafisika semata dan cenderung mengabaikan persoalan fisika (kealaman)? Jika demikian, bagaimana dengan kemajuan ilmu dan peradaban yang pernah dicapai oleh Islam di masa itu. Bukankah fakta ini menunjukkan bahwa pemikir muslim menjadikan kedua persoalan itu (fisika dan metafisika) sebagai objek keilmuannya? Menurut Mujamil Qomar (2007: 32-33), selama ini ilmu pengetahuan dalam Islam lebih menitikberatkan persoalan aksiologi yang merupakan weltanschaung dan berfungsi seabagi landasan dalam menginstruksi fakta. Islam tidak menghendaki keterpisahan amtara ilmu dan sistem nilai, seperti yang terjadi di Barat. Ilmu adalah fungsionalisasi ajaran wahyu. Ilmu merupakan hasil dialog antara ilmuan dengan realitas yang diarahkan perkembangannya oleh al-Qur'an. Dengan demikian, Islam menolak science for science dan menghendaki keterlibatan moralitas dalam pencarian kebenaran ilmu.

Jika pandangan-pandangan di atas dapat diterima, maka dapat ditarik benang merah bahwa diskursus epistemologi (filsafat pengetahuan) yang berkembang dalam Islam di masa lalu lebih 
terfokus pada aspek ontologi dan aksiologi, dan kurang membahas aspek epistemologi (metode keilmuan). Pada aspek ontologi pun, perhatian lebih tercurah pada persoalan metafisika. Selanjutnya, bagaimana dengan studi hadis yang telah melahirkan banyak cabang keilmuan dan dianggap oleh sebahagian ulama sebagai ilmu yang telah mapan?

\section{Pengertian Kritik Hadis}

Secara bahasa, kritik berarti kecaman atau tanggapan, kadang-kadang disertai uraian dan pertimbangan baik buruk terhadap suatu hasil karya, pendapat dan sebagainyi (http://kbbi.web.id/kritik), atau bersifat tidak cepat percaya, tajam dalam penganalisaan, ada uraian pertimbangan baik buruk terhadap suatu karya (Depdikbud: 1988, 466). Jika kata ini disandingkan dengan kata hadis, maka yang dimaksud dengan kritik hadis adalah penilaian baik atau buruk terhadap sebuah hadis. Penilaian ini dilakukan untuk mengetahui otentisitas atau keaslian penisbahan sebuah hadis kepada Rasulullah saw. Adapun wujud dari penilaian tersebut berupa pengetahuan tentang kualitas hadis; shahih, hasan, ataukah dha'if.

Pemaknaan kritik hadis seperti $\mathrm{di}$ atas didasarkan atas pengertian naqd al-hadis. ${ }^{1}$ Sebagaimana dimaklumi, dalam literatur ilmu hadis, istilah kritik merupakan padanan kata 'naqd' ( ) yang secara bahasa bermakna melakukan seleksi atas sesuatu dengan cara memisahkan antara yang baik dan yang buruk (Muhammad Ali Qasim : t.th., 11). Agaknya, adanya kesamaan makna antara kedua kata ini menyebabkan kata kritik dipakai untuk menerjemahkan kata al-naqd (naqd al-hadis atau kritik hadis). Adapun menurut istilah, naqd dipahami dengan menyeleksi atau memisahkan hadis shahih dari hadis dhaif, serta menetapkan status perawinya dari segi ke-tsiqah-an dan kecacatannya (M.M. Azami : 1990, 5). Dengan makna ini, maka kritik hadis (naqd al-hadis atau uji otentisitas hadis) dapat dipahami sebagai suatu aktivitas penelitian kualitas hadis. Bagi sebahagian muhaddisin, kegiatan kritik hadis ini kemudian berkembang menjadi satu cabang ulumul hadis yang disebut ilmu kritik hadis (atau 'ilm naqd al-hadis) yang didefinisikan sebagai:

هو علم يبحث في تمييز الأحاديث الصحيحة من الضعيفة و بيان عللها والحكم على رواتها جرحا وتعديلا بألفاظ مخصوصة ذات دلائل معلومة عند أهل الفن .

Ilmu yang membahas tentang bagaimana membedakan atau memisahkan hadis shahih dari yang dha'if, menjelaskan 'illat-'illat dan hukum para perawinya; baik berupa jarh atau ta' dil, dengan

\footnotetext{
${ }^{1}$ Menurut Ali Mustafa Ya'qub, Ibn Abi Hatim (w. 327 H) adalah orang yang pertama kali menggunakan istilah al-naqd untuk menggambarkan aktivitas keilmuan tersebut, seperti dijumpai dalam kitabnya al-Jarh wa al-Ta'dil. Dalam karyanya ini, ia juga menyebut istilah kritik dan kritikus hadis (al-naqd wa al-nuqqad). Sebelumnya, istilah yang dipakai adalah tamyiz (pembedaan). Ini dapat dilihat pada salah satu kitab karya Imam Muslim ibn Hajjaj (w. $261 \mathrm{H})$ yang membahas kritik hadis berjudul al-Tamyiz. Ali Mustafa Yaqub, Kritik Hadis, (Pustaka Firdaus, Jakarta, 2000), hal. xiv; Hasjim Abbas, Kritik Hadis Versi Muhaddisin dan Fuqaha, (Yogyakarta: Teras, 2004), hal. 9
} 
menggunakan istilah khusus yang memiliki makna tertentu menurut oleh para ahli ilmu ini (Muhammad Ali Qasim : t.th., 11).

\section{Epistemologi Kritik Hadis}

Sebagaimana telah dijelaskan sebelumnya, kajian pokok epistemologi adalah tentang hakikat pengetahuan, validitas kebenaran serta sumber dan metode untuk memperoleh pengetahuan. Jika persoalan epistemologi ini diarahkan kepada kritik hadis, maka pertanyaan yang muncul adalah apakah hadis itu, apa yang menjadi dasar dan sumber hadis; bagaimana cara mengetahui kebenaran atau otentisitas sebuah hadis; bagaimana menguji kebenaran metode otentisitas tersebut.

Epistemologi kritik hadis diawali dari pemikiran bahwa hadis, yang sekarang berwujud teks keagamaan, merupakan sumber pengetahuan karena memuat informasi tentang segala sesuatu yang berasal atau tentang diri Nabi dan diyakini sebagai sumber ajaran Islam. Informasi ini diperoleh dari orang-orang yang hidup semasa dengan Nabi, dan dikenal dengan istilah shahabat. Mereka-lah yang kemudian menyampaikan informasi tersebut kepada generasi di bawahnya, tabi'in, yang kemudian menyampaikannya lagi kepada generasi di bawah mereka, tabi tabi'in. Proses ini berlanjut hingga diterima oleh para perawi yang kemudian menghimpunnya dalam karya-karya mereka, seperti alMuwaththa' karya Malik ibn Anas (w. 179 H), al-Musnad karya Ahmad ibn Hanbal (w. 241 H) dan Kutubussittah. Buah karya para penghimpun hadis (al-mukharrij al-hadis) abad II dan III H inilah yang kemudian menjadi sumber pengetahuan dan rujukan hadis pada masa-masa berikutnya hingga sekarang (Syuhudi Ismail: 1998, 32-33).

Persoalan yang timbul kemudian adalah bagaimana menjadikan sebuah hadis dapat diyakini atau diduga kuat berasal dari Nabi saw., mengingat hadis - sebagai sebuah laporan, adalah data sejarah yang menceritakan sebuah peristiwa yang terjadi di masa lalu, dalam hal ini kehidupan Rasulullah. Apa alat ukur (metode) yang dapat dipakai untuk menguji sebuah hadis hingga diyakini keotentikannya berasal dari Rasulullah saw. Pertanyaan ini semakin menguat jika melihat sejarah perjalanan hadis yang diriwayatkan oleh banyak perawi dengan karakter yang beragam, hadis juga 'rentan' mengalami pemalsuan dan penyimpangan, serta proses periwayatannya yang cenderung bersifat ahad, sehingga menjadikan problem otentisitas hadis menjadi diskursus yang sangat marak bahkan sejak Rasulullah saw, wafat. Selanjutnya, problem yang muncul setelah sebuah hadis diyakini berasal dari Nabi (otentik) adalah bagaimana ia harus dipahami agar dapat bermakna dalam kehidupan kekinian (dapat diamalkan).

Terkait dengan pertanyaan-pertanyaan epistemologi di atas, para ulama menjelaskan bahwa setiap hadis yang hendak dijadikan sebagai sumber ajaran harus melewati 'dua tahap pengujian', yaitu kritik hadis (naqd al-hadith) dan pemahaman hadis (fiqh al-hadith atau syarh al-hadis). Kajian 
pertama mengarah kepada problem otentisitas hadis dengan sasaran akhir berupa pengetahuan tentang kualitas sebuah hadis; apakah shahih, hasan, atau dha'if, sebagai upaya awal untuk mengetahui apakah hadis tersebut diyakini atau diduga yakin berasal dari Nabi atau tidak. Adapun kajian kedua merupakan lanjutan dari kritik hadis, dimana kegiatan ini dilakukan terhadap kandungan matan hadis yang maqbul (berkualitas shahih atau hasan), dengan sasaran akhir untuk mengetahui apakah hadis tersebut dapat menjadi hujjah dan dapat diamalkan; atau tidak. Apakah nilai yang terkandung didalamnya berdimensi syariat atau tidak. Jika berdimensi syariat, apakah bersifat temporal atau universal. Dua 'kegiatan' inilah yang kemudian melahirkan satu disiplin keilmuan Islam, yaitu ulum al-hadis dengan berbagai cabangnya.

Mengenai dasar penetapan kriteria keshahihan hadis, harus dimaklumi bahwa hadis pada hakekatnya adalah data historis yang berisi informasi tentang segala sesuatu yang berasal dari Nabi. Data historis ini diketahui dari laporan shahabat kepada tabi'in dan tabi' tabi'in hingga akhirnya dikodifikasi dalam kitab-kitab hadis yang terpelihara hingga sekarang. Dalam peng-kodifikasi-an ini, para mukharrijul hadis mencatat tidak hanya informasi tersebut, tetapi juga rangkaian orang yang menyampaikannya. Dalam ilmu hadis, informasi ini disebut teks hadis atau matan, sementara rangkaian orang yang menjadi mata rantai dalam periwayatan matan disebut sanad. Inilah dua unsur utama pembentuk hadis (M. Syuhudi Ismail: 1989, 25; Musfir Abdullah Al-Damini: 1984, 49).

Persoalan yang muncul selanjutnya adalah bagaimana mengetahui keaslian atau kebenaran (otentisitas) dari sebuah hadis. Hal ini menjadi sesuatu yang penting mengingat kedudukan hadis sebagai sumber ajaran dan banyaknya persoalan yang mengitari sejarah periwayatannya, seperti banyaknya para pelaku bid'ah dan hawa nafsu yang ikut meriwayatkan hadis dan orang-orang yang membuat riwayat-riwayat palsu, yang kemudian dinisbahkan kepada Rasulullah (hadis mawdhu'). ${ }^{2}$ Atas dasar ini, maka para ulama membuat sejumlah kriteria agar sebuah hadis dapat diakui dan diterima sebagai sumber ajaran. Rumusan kriteria inilah yang kemudian menjadi sebuah kaedah dan disepakati sebagai parameter persyaratan untuk menguji sebuah hadis. Kaedah inilah yang menjadi dasar pelaksanaan kritik hadis (naqd al-hadis).

Kaedah kritik ini berupa syarat keshahihan hadis yang terdiri atas sejumlah kriteria yang harus dipenuhi oleh suatu hadis untuk diyakini berasal dari Nabi dan dapat dipakai sebagai sumber ajaran agama. Para ahli hadis awal sampai abad ketiga Hijrah tidak secara eksplisit mendefinisikan hadis-hadis yang dapat dianggap shahih. Mereka hanya menetapkan kriteria-kriteria informasi yang

\footnotetext{
${ }^{2}$ Beberapa persoalan yang muncul di sekitar periwayatan hadis dan mendorong dilakukannya kegiatan kritik hadis secara massive, terutama jarh wa ta'dil terhadap para perawi adalah (1) Mulai melemahnya kemampuan umat dalam menghafal hadis, (2) Perkembangan sanad hadis yang semakin panjang dan bercabang, (3) Banyak munculnya firqah-firqah yang dinilai menyimpang dari manhaj shahabat dan tabi'in. Nuruddin 'Itr, Manhaj al-Naqd fi 'Ulum alHadis, (Damaskus: Dar al-Fikr, 1988), hal. 58
} 
diperoleh, yang didasarkan atas kualitas dan karakter perawi yang menetukan diterima dan ditolaknya riwayat mereka. Namun, kriteria ini belum mencakup secara keseluruhan syarat keshahihan hadis (Kamaruddin Amin: 2009, 16). Dalam hal ini, Imam al-Syafi'i (w. 204 H) dipandang sebagai tokoh yang berjasa dalam perumusan kaedah tersebut secara tertulis dan kitabnya, al-Risalah dan al-Umm, merupakan sumber tertua yang masih terpelihara hingga sekarang (Nuruddin 'Itr: 1988, 58; Kamaruddin Amin: 2009, 15). Demikian halnya dengan Bukhari, Muslim serta yang lainnya dari periode mutaqaddimin telah memperjelas benih-benih itu dan menerapkannya pada hadis-hadis yang mereka teliti dan mereka riwayatkan. Kemudian ulama pada zaman berikutnya menyempurnakan benih-benih kaedah itu ke dalam rumusan kaedah yang selanjutnya berlaku sampai sekarang (M. Syuhudi Ismail: 1989, 63-64).

Salah seorang ulama hadis muta'akhirirn yang menyusun secara komprehensif rumusan kaedah ke-shahih-an hadis ialah Abu Amr Usman ibn Abdurrahman ibn al-Shalah al-Syahrazuriy (w. $643 \mathrm{H})$, yang dikenal dengan nama Ibn al-Shalah (1984: 11-12). Menurutnya:

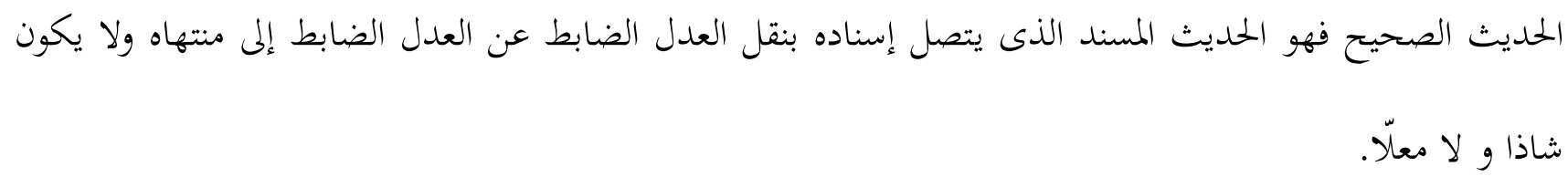

Hadis shahih ialah hadis yang bersambung sanad-nya, diriwayatkan oleh perawi yang 'adl dan dhabith, berasal dari perawi yang juga 'adl dan dhabith hingga kepada akhir sanad, tidak terdapat syaz (kejanggalan) dan 'illat (cacat).

Berangkat dari definisi ini dapat disimpulkan bahwa unsur keshahihan hadis mencakup (1) Sanad hadis harus bersambung mulai dari mukharrij hingga kepada Nabi, (2) Seluruh perawi hadis yang membentuk rangkaian sanad harus mempunyai sifat 'adil, (3) Mereka juga harus memiliki sifat dhabith, (4) Hadis tersebut tidak memiliki kejanggalan (syaz), dan (5) Terhindar dari kecacatan ('illat). Dari unsur-unsur-unsur ini, Syuhudi (1989: 64-65) menjelaskan bahwa kelimanya berhubungan dengan sanad, dan hanya dua unsur, yaitu terhindar dari syaz dan 'illat, berlaku untuk matan. Karena itu, dalam tataran praktis, ada tujuh kriteria yang harus diterapkan untuk menguji keshahihan sebuah hadis.

Terkait dengan kritik sanad, uji keshahihan dilakukan pada aspek kebersambungan periwayatan dan kualitas perawi yang membentuk periwayatan tersebut. Pada aspek inilah perlu diteliti secara mendalam biografi setiap perawi. Penelitian ini terfokus pada nama, tempat, tahun lahir dan wafat. Bahkan sikap dan kepercayaan keagamaannya pun harus dievaluasi secara hati-hati. Sebab, informasi ini dipercaya dapat membantu ulama yang kritis bukan hanya dalam upaya 
menetapkan ke-tsiqah-an para perawi, tetapi juga untuk menentukan kemungkinan dan ketidakmungkinan bahwa perawi telah menjalin hubungan intelektual dengan para informannya (hubungan guru-murid dengan perawi sebelumnya). Menyangkut hubungan ini, penelitian kata-kata yang menghubungkan seorang perawi dengan perawi lainnya menjadi sangat penting, karena katakata yang digunakan oleh perawi ditengarai mengandung implikasi tentang cara periwayatan hadis. Kata-kata yang sering dipakai adalah sami'tu, haddatsna, akhbarana, anna, 'an, dan lainnya, dianggap memiliki implikasi makna yang berbeda karena masing-masing menggambarkan berbagai kemungkinan hubungan dalam proses periwayatan.

Pada awalnya, informasi tentang para perawi ini diketahui oleh ulama kritikus hadis melalui penyampaian secara verbal (lisan) ketika mereka belajar hadis ataupun melakukan perjalanan (rihlah) untuk mencari hadis. Seiring dengan maraknya tradisi penulisan, informasi ini kemudian dicatat oleh para penulis kitab-kitab biografi perawi hadis, seperti Kitab Al-Thabaqat al-Kabir karya Ibn Sa'ad (w. $230 \mathrm{H}$ ), Al-'Ilal karya Ali al-Madini (w. 234 H), Kitab Al-'Ilal wa Ma'rifat al-Rijal karya Ahmad ibn Hanbal (w. 241 H), Tarikh Al-Kabir karya al-Bukkhari (w. 256 H), dan Kitab al-Jarh wa alTa'dil karya Ibn Abi Hatim al-Razi (w. 328 H). Inilah kitab-kitab yang dianggap paling awal memuat informasi tentang para perawi hadis.

Adapun kritik matan dilakukan untuk mengetahui kualitas matan sebuah hadis. Upaya ini harus dilakukan karena sebuah hadis dikatakan berkualitas shahih apabila sanad dan matannya samasama berkualitas shahih. Kritik matan sendiri dilakukan setelah sanadnya diketahui kualitasnya. Jika sanad dari matan tersebut berkualitas shahih, atau minimal tidak berat ke-dhaif-annya, maka kritik matan dapat dilanjutkan. Tetapi apabila sanadnya sangat dhaif maka matan hadis tersebut tidak perlu diteliti sebab hasilnya tidak akan memberi manfaat bagi kehujahannya.

Dalam kegiatan kritik matan, unsur yang harus dipenuhi oleh suatu matan yang berkualitas shahih adalah terhindar dari syaz (kejanggalan) dan 'illah (cacat). Berangkat dari dua kriteria utama ini, para ulama kemudian merumuskan tolok ukur penelitian matan (mi'yar naqd al-matn) sebagai acuan dalam menilai keshahihan hadis. Hanya saja, mengingat kedua kriteria ini masih sangat umum, maka pada tataran praksis rumusan yang dibuat ulama menjadi tidak seragam, bahkan terkadang tumpang tindih dalam perumusannya. Seperti al-Khatib al-Baghdadi (w.463 H) yang menetapkan bahwa suatu matan hadis dinyatakan maqbul apabila: (1) tidak bertentangan dengan akal, (2) tidak bertentangan dengan hukum al-Qur'an yang telah muhkam, (3) tidak bertentangan dengan hadis mutawatir, (4) tidak bertentangan dengan amalan yang telah menjadi kesepakatan ulama masa lalu, (5) tidak bertentangan dengan dalil yang telah pasti, dan (6) tidak bertentangan dengan hadis ahad yang kualitas keshahihannya lebih kuat (Syuhudi ismail: 1989, 126). Sementara Ibn al-Jawzi (w. 597 
H) mengemukakan penjabaran kriteria syaz dan 'illat pada matan melalui pernyataan yang cukup singkat, yaitu: فكل حديث رأيته يخالف المعقول أو يناقض الأصول فاعلم أنه موضوع (Setiap hadis yang menurut pendapatku bertentangan dengan akal atau menyalahi ketentuan pokok agama maka ketahuilah bahwa hadis tersebut adalah palsu) (Shalahuddin Al-Idlibiy: 1983, 237).

Berangkat dari perbedaan perumusan kriteria keshahihan matan yang terjadi di antara para ulama dan setelah melakukan perbandingan antara kriteria yang mereka rumuskan, Shalahuddin alIdhibi (1983: 238), menyimpulkan bahwa persyaratan tidak mengandung syaz dan 'illat, ketika dirumuskan menjadi kaedah kritik matan menjadi empat kriteria, yaitu (1) tidak bertentangan dengan petunjuk al-Qur'an, (2) tidak bertentangan dengan sesuatu yang sudah tetap (tsabit) dari hadis dan sirah nabawiyah, (3) tidak bertentangan dengan akal, panca indra atau sejarah, dan (4) susunan matan tersebut menunjukkan ciri-ciri perkataan Nabi.

Inilah gambaran umum kaedah keshahihan hadis, baik yang terkait dengan kritik sanad ataupun kritik matan. Kaedah inilah yang diyakini oleh mayoritas ulama telah diterapkan oleh ulama abad kedua dan ketiga Hijriah ketika mereka melakukan upaya tadwin atau kodifikasi hadis dan selanjutnya disistematisasikan dalam sebuah rumusan teoretik keshahihan hadis. Pada gilirannya, upaya penerapan kaedah ini melahirkan banyak cabang ilmu hadis, seperti ilmu rijal al-hadis dan ilmu mukhtalif al-hadis. Ilmu-ilmu inilah yang kemudian membentuk satu disiplin keilmuan Islam yang dikenal dengan 'Ulumul Hadis.

\section{Rekonstruksi Epistemologi Kritik Hadis: Wacana Pengembangan Keilmuan}

Pertanyaan yang muncul terhadap epistemologi kritik hadis seperti diuraikan di atas adalah bagaimana analisis terhadap metode kritik hadis yang bertujuan menguji keotentikan hadis dari sudut pandang filsafat ilmu?

Terkait dengan kritik sanad, jika perhatian diarahkan kepada masa hidup para penulis kitab biografi perawi hadis, disinilah muncul problem epistemologi. Problem tersebut adalah bagaimana mengukur keakuratan informasi yang mereka sampaikan mengingat biografi tersebut bukanlah hasil dari pengamatan langsung, melainkan ditulis jauh setelah para perawi wafat, terutama jika diukur dari masa hidup Nabi dan para shahabatnya; dan apakah parameter untuk menentukan cacat tidaknya seorang perawi pada masa itu sudah cukup valid. Atau dalam bahasa epistemologi, sejauh mana otoritas (kesaksian) mereka dapat diterima dan menjadi sumber pengetahuan mengingat keraguan dan bahkan penolakan para ilmuwan modern terhadap kebenaran yang bersumber dari metode ini. Pertanyaan ini timbul karena seperti telah dijelaskan bahwa sebuah kebenaran otoritas dapat diterima jika berasal dari orang yang dapat dipercaya. Oleh sebab itu, bagi sebahagian ilmuwan, otoritas tidak 
dapat dijadikan sumber pertama dalam pengetahuan dan bahkan dapat berbahaya jika tidak diselidiki secara sempurna. Disinilah persoalan muncul, ketika kebenaran hadis dihadapkan kepada sarjana Barat. Mereka meragukan - bahkan menolak otentisitas hadis mengingat sumber pengetahuan ini berasal dari otoritas (kesaksian) para perawi hadis, terutama yang hidup di abad ketiga Hijrah.

Bagi ulama hadis, informasi yang terdapat dalam kitab biografi perawi dinilai akurat dan dapat dipertanggungjawabkan karena didasarkan pada keterangan para ulama kritikus hadis (alnuqaad) yang diakui kredibilitasnya, semisal Syu'bah ibn al-Hajjaj (w. 160 H), Yahya ibn Sa'id alQaththan (w. 198 H), Yahya ibn Ma'in (w. 233 H), Ali al-Madini (w. 234 H), dan Ahmad ibn Hanbal (w. $241 \mathrm{H}$ ). Para al-nuqad inilah yang tercatat dalam sejarah melakukan perjalanan untuk mencari sebuah hadis (rihlah) (Imaduddin Muhammad Rasyid: t.th., 84, 362). Mereka juga meyakini bahwa kegiatan kritik sanad telah dilaksanakan, bahkan sejak masa shahabat, pasca terjadinya al-fitnat alkubra seperti disinyalir oleh Ibn Sirin ( w. 110 H) (Muslim ibn Hajjaj: 1998, 24). Tradisi ini kemudian dilanjutkan oleh para tabi'in, seperti Abu Abdurrahman al-Salami (w. 72/80 H), Said ibn al-Musayyab (w. 93 H), al-Qasim ibn Muhammad ibn Abu Bakar, Salim ibn Abdullah, Urwah ibn alZubayr, al-Zuhriy, Ibrahim al-Nakha'iy (w. 96 H), al-Sya'biy (w. 103 H), dan Ibn Sirin (M.M. A'zhami : 1990, 11-12; Mahmud Thahir al-Jawwabi: 1997, 83-86). Baru pada abad abad III, informasi dari para al-nuqaad ini dicatat oleh para ulama dalam kitab-kitab biografi rijal hadis seperti yang dijumpai sekarang. ${ }^{3}$

Berbeda dengan sikap menerima yang ditunjukkan oleh umumnya ulama hadis terhadap kitab-kitab biografi perawi serta informasi di dalamnya, para sarjana Barat bersikap apatis terhadap terhadap kitab-kitab tersebut. Bahkan cenderung menolak semua informasi tersebut. Penolakan ini didasarkan atas argumentasi keilmuan bahwa sumber-sumber historis baru dapat digunakan apabila ditulis sezaman dengan peristiwa tertentu. Dalam metodologi historis, sumber-sumber yang ditulis belakangan harus didukung oleh data-data lain yang memperkuat, misalnya hasil ekskavasi arkeologis atau sumber-sumber di luar tradisi itu sendiri (Mun'im A. Sirry: 2015, 219). ${ }^{4}$ Karena itu,

${ }^{3}$ Terkait dengan biografi para perawi hadis ini, Sprenger, orientalis Jerman, dalam pengantar Kitab al-Ishabah fi Tamyiz al-Shahabah karya Ibn Hajar al-'Asqalani, berkata: "Tidak ada satupun dari bangsa-bangsa terdahulu dan juga pada bangsa-bangsa sekarang yang menghasilkan karya seperti Ilmu Asma’ Rijal (Ilmu yang memuat biografi para perawi hadis) seperti disusun oleh umat Islam dalam ilmu yang agung ini. Ilmu ini memuat informasi dan hal ihwal sekitar 500.000 perawi hadis”. Muhammad “Ajjaj al-Khatib, al-Sunnah Qabla al-Tadwin, (Beirut: Dar al-Fikr, 2001), hal. 157

${ }^{4}$ Mun'im juga menjelaskan ada 3 (tiga) argumen kenapa sumber-sumber tradisional (Islam) bermasalah. Pertama, sumber-sumber tersebut ditulis jauh setelah Rasulullah wafat, lebih kurang 100 tahun jika mengacu kepada sumber sirah tertua, yakni Sirah Ibn Ishaq (w. 150 H). Padahal bagi kalangan sejarawan, sumber-sumber tertulis harus sezaman dengan peristiwa yang terjadi. Kedua, banyak narasi yang disebutkan dalam sumber-sumber tradisional lebih merefleksikan perkembangan belakangan yang diproyeksikan ke masa Nabi. Aspek-aspek politis, teologi dan hukum yang menjadi perdebatan di kemudian hari mempengaruhi dan membentuk narasi-narasi historis. Ketiga, banyak narasi dalam sirah bersifat kontradiktif. Sebagian kontradiksi itu dapat direkonsiliasi, dan sebagian lain tidak. Adanya kontradiksi tersebut tidak berarti keseluruhan peristiwa dalam sirah bersifat fiktif, melainkan diperlukan kehati-hatian 
mengingat hadis merupakan data sejarah kehidupan Nabi yang didasarkan atas informasi orang-orang yang hidup sezaman dengannya (shahabat), maka seyogyanya dokumen tertulis tentang hadis harus berasal dari catatan para shahabat. Demikian halnya dengan informasi tentang shahabat harus didasarkan atas catatan tertulis yang berasal dari sesama mereka atau dari generasi yang semasa (tabi'in). Problemnya adalah sumber tertulis yang terkait dengan sirah adalah kitab Sirah Ibn Ishaq yang merupakan biografi Nabi paling awal dan masyhur, dan ditulis oleh Ibn Ishaq (w. $150 \mathrm{H}$ ) lebih dari satu abad setelah Nabi meninggal. ${ }^{5}$ Kitab hadis paling awal yang terpelihara hingga sekarang adalah al-Muwaththa' yang ditulis oleh Imam Malik (w. 179 H) (Nuruddin 'Itr: 1988, 58-59). Sementara untuk biografi perawi hadis, kitab yang paling awal ditulis adalah Thabaqat Ibn Sa'ad karya Ibn Sa'ad (w. 230 H) (Muhammad 'Ajjaj al-Khatib: 1988, 273-274; Mahmud Thahhan, 1996, 152-153). Penetapan ketiga kitab ini sebagai sumber tertulis paling awal sendiri didasarkan atas masa hidup para penulisnya yang mendahului ulama lain yang menulis karya yang sama.

Secara umum, penolakan sumber-sumber tertulis di atas sebagai sumber pengetahuan dapat dilacak dalam karya-karya sarjana Barat dan beberapa pemikir muslim modern, seperti Fazlur Rahman (Abdul Fatah Idris : 2012, 78-80; Faiqotul Mala: 2015, 40-43). Penolakan ini sendiri, seperti telah dijelaskan, karena 'data sejarah' yang terdapat dalam kitab-kitab tersebut ditulis jauh setelah peristiwa itu terjadi dan hanya didasarkan atas kesaksian (otoritas) sumber yang semasa hidupnya dengan para penulis kitab tersebut. Padahal untuk diakui sebagai sebuah peritiwa sejarah, sebuah dokumen sejarah harus ditulis pada saat peristiwa sejarah itu terjadi. Dengan kata lain, data sejarah itu didasarkan atas pengamatan indrawi (empiris).

Terkait dengan kriteria kritik matan, dapat dinyatakan bahwa dalam menentukan 'kebenaran' atau otentisitas sebuah matan hadis, uji kebenaran yang ditempuh ulama adalah teori kebenaran koherensi (kesesuaian antara suatu pernyataan dengan pernyataan lain). Ini terlihat dari pernyataan bahwa sebuah teks dinyatakan shahih jika tidak bertentangan dengan al-Qur'an, hadis dan sirah nabawiyah yang sudah tsubut, akal, panca indra dan fakta sejarah. Pertanyaan yang muncul kemudian apakah kriteria ini sudah ada sebelum kodifikasi hadis dilakukan dan sejauh mana konsistensi para ulama penyusun kitab-kitab hadis mu'tabar dalam penerapannya?

dalam merekonstruksi sejarah kehidupan Nabi. Atas dasar argumentasi ini, banyak sejarawan Barat yang bersikap skeptis. Bahkan Michael Cook dan Patricia Crone (1977), yang beraliran revisonis radikal menyatakan bahwa sumbersumber tradisionalis yang didasarkan pada data-data yang bermasalah secara historis dan ditulis belakangan tidak dapat dikatakan memiliki sejarah. Menurut keduanya, kisah-kisah dan episode kehidupan Nabi yang disajikan literatur sirah merupakan bentuk idealisasi mitos yang dibuat oleh kaum muslim belakangan. Mun'im A. Sirry, Kontroversi Islam Awal Antara Mazhab Tradisionalis dan Revisionis, (Bandung: Mizan 2015), hal. 219-221

${ }^{5}$ Karya asli Ibn Ishaq yang ada saat ini merupakan bagian yang diedit oleh sejarawan asal Mesir, Ibn Hisyam (w. 208 H). Namun demikian, sarjana-sarjana modern meyakini bahwa apa yang disalin oleh Ibn Hisyam secara genuine merepresentasikan karya orisinal Ibn Ishaq. Mun'im A. Sirry, Kontroversi Islam Awal..., hal. 215, 218 
Dari penjelasan pada bab sebelumnya, diketahui bahwa sejak masa shahabat telah ada uji kritik matan yang dilakukan berupa uji kebenaran bahwa Rasulullah jelas-jelas menginformasikan hadis itu. Prosedur yang mereka lakukan mencerminkan upaya memperoleh hasil dari perujukan silang sehingga diketahui hakekat dari kebenaran teks hadis tersebut. Pola perujukan silang ini lebih berupa mengadu kebenaran pernyataan hadis dengan al-Qur'an, hadis dan akal. Atau dalam kacamata filsafat berupa uji koherensi. Menurut Hasjim Abbas, pola perujukan silang teks hadis yang dilakukan shahabat mengambil tiga bentuk, yaitu (1) Metode muqaranah atau perbandingan antara riwahat hadis dari sesama shahabat, seperti kasus Khalifah Abu Bakr yang menolak pemberitaan Mughirah ibn Syu'bah tentang bahagian warisan nenek hingga ada kesaksian serupa dari Muhammad ibn Maslamah. (2) Metode mu'aradhah berupa pencocokan konsep yang menjadi muatan pokok matan hadis dengan al-Qur'an, hadis, sirah nabawiyah, dan akal sehat. Contohnya penolakan Khalifah Umar terhadap hadis Fathimah binti Qays tentang ketiadaan nafqah istri yang ditalak baik oleh suami. Menurut Umar, kesaksian Fathimah ini bertentangan dengan QS. Al-Thalaq: 1 (Hasjim Abbas: 2004, 28-31).

Informasi ini memberikan gambaran bahwa sejak periode shahabat uji kritik matan hadis telah dilakukan secara ketat. Sikap shahabat inilah yang kemudian diikuti dan dirumuskan oleh para ulama pada periode berikutnya sehingga menjadi 'acuan' dalam menghimpun hadis selama periode tadwin atau kodifikasi hadis. Kaedah ini sendiri, selanjutnya menjadi disepakati ulama menjadi sebuah kaedah keshahihan hadis yang baku.

Pertanyaan epistemologi yang muncul kemudian adalah sejauh mana teori kebenaran koherensi ini dipakai dalam melakukan uji kritik matan. Maksudnya apakah para ulama para penghimpun kitab-kitab hadis ini bersikap konsisten dalam penerapan kaedah kritik matan hadis yang dicontohkan para shahabat di atas. Pertanyaan ini patut diajukan mengingat adanya sejumlah hadis dalam kitab-kitab hadis tersebut yang tidak memenuhi kriteria di atas. Karena itu, tidak heran jika kemudian sejumlah pemikir muslim modern meragukan konsistensi para ulama penghimpun hadis dalam penerapannya. Bahkan seperti dijelaskan oleh Kamaruddin Amin (2009: 6, 60), Ibn Khaldun dan beberapa pemikir muslim modern, seperti Ahmad Amin dan Abu Rayyah menegaskan bahwa terjadi pengabaian uji kritik matan selama proses kodifikasi tersebut. Sementara ia sendiri menilai bahwa para ulama tersebut tetap memberi perhatian terhadap kritik matan, hanya saja uji kritik yang dilakukan lebih bersifat sekunder. Fokus perhatian tentu saja lebih diarahkan kepada uji kritik sanad.

Untuk menjawab 'lubang epistemologi' kritik hadis ini, para pemikir muslim modern menyatakan bahwa dari kacamata filsafat tidak berarti bahwa sumber pengetahuan yang didasarkan 
atas otoritas harus dinafikan atau dibuang sama sekali. Pengetahuan yang didasarkan atas otoritas tetap dapat diterima jika ada bukti lain yang mendukung atau menguatkan pengetahuan tersebut. Karena itu, seperti dijelaskan oleh Mun'in A. Sirry (2015: 220) bahwa pada kitab-kitab tersebut masih tersimpan aspek-aspek historis (historical kernel). Yang diperlukan ialah kriteria dan metode tertentu untuk mendeteksi narasi-narasi yang bersifat historis dan membedakannya dari cerita-cerita yang tak jelas ujung pangkalnya. Hal senada diungkapkan oleh Kamaruddin Amin (2009: 33). Menurutnya, kutub al-rijal, kutub al-thabaqat, dan kutub al-jarh wa al-ta'dil yang memberikan informasi tentang para perawi hadis tidak harus diabaikan sama sekali. Kitab-kitab ini terlalu penting untuk diabaikan. Tetapi, semua kitab ini tetap harus diperlakukan secara kritis. Upaya inilah yang dilakukan oleh beberapa pemikir muslim modern ketika mereka mengkritisi pandangan para sarjana Barat terkait dengan hadis dan keilmuan yang melingkupinya.

Hanya saja, berbeda dengan para pendahulunya yang lebih menekankan pada aspek kritik sanad, metode yang dikembangkan oleh para pemikir muslim modern untuk menutupi 'lubang epistemologi kritik sanad' adalah dengan berpaling kepada rekonstruksi kritik matan semata, dan atau kepada penggabungan kritik sanad dan matan secara proporsional dan berimbang. Pengembangan metode pertama ini disuarakan antara lain oleh Fazlur Rahman yang bersikap apatis terhadap sistem sanad. Menurutnya, sanad harus dibuktikan dengan sejarah dan itu merupakan sesuatu yang sulit. Ia juga menyatakan bahwa sistem sanad berlembang di belakang hari, yaitu menjelang akhir abad pertama Hijrah. Karena itu, Rahman kemudian mengembangkan metode kritik matan dengan pendekatan hermeneutika dan pendekatan situasional (historis) (Abdul Fatah Idris: $2012,79,81)$.

Adapun metode kedua dikembangkan antara lain oleh M.M. A'zami, Fuat Sezgin, Nabia Abbot, dan Kamaruddin Amin. Seperti penelitian yang dilakukan oleh M.M. A'zhami yang menemukan bahwa pada jenjang ketiga (thabaqah tsalitsah) dari tingkatan perawi ada yang mencapai jumlah antara 20 - 30 orang dengan domisili yang terpencar dan berjauhan, dari India sampai Maroko, atau dari Turki sampai Yaman. Sementara redaksi hadis yang mereka riwayatkan itu sama. Karena itu, mustahil jika mereka pernah berkumpul untuk membuat hadis palsu dengan redaksi sama. Temuan M.M. A'zhami sendiri mengindikasikan bahwa terdapat bukti konkret yang menunjukkan penulisan hadis telah dimulai sejak abad pertama Hijrah atau sejak Nabi masih hidup (Faiqotul Mala: 2015, 45,49). Adanya bukti ini mengindikasikan bahwa sanad bukanlah rekayasa ulama abad kedua atau ketiga Hijrah dan pertemuan antara antar perawi merupakan sebuah fakta sejarah yang benar-benar terjadi karena didukung data-data yang valid. Pembuktian ini dilakukan dengan melakukan uji kritik matan hadis. 
Demikian halnya dengan Kamaruddin Amin yang menggunakan metode isnad cum matan untuk menguji keotentikan hadis; suatu metode kritik hadis yang mengkombinasikan analisis isnad dan matan (Kamaruddin Amin: 2009, 60). Sebuah metode yang diakui Harold Motzki (2009: viii-ix) memiliki keunggulan dalam mengetahui penanggalan (dating atau kapan munculnya) hadis hingga ke masa yang jauh lebih awal dibanding metode para orientalis, yaitu hingga periode shahabat (awal abad pertama Hijriah). Menurut Kamaruddin Amin, metode isnad cum matan merupakan sebuah analisis yang seksama karena melakukan perbandingan terhadap variasi atau keragaman matan sebuah hadis. Keragaman ini sendiri kebanyakan berupa penambahan-penambahan redaksional yang antara satu dengan lainnya sangat berbeda secara signifikan. Kasus seperti ini bahkan ditemukan dalam kitab-kitab hadis yang dianggap paling otentik, Shahih al-Bukhari dan Shahih Muslim. Umumnya, ulama hadis menerima tambahan-tambahan tersebut jika berasal dari perawi yang terpercaya (al-ziyadat 'an al-tsiqat), tetapi sarjana Barat dan beberapa pemikir muslim modern bersikap kritis atas tambahan tersebut. ${ }^{6}$ Demikian pula, kalau mayoritas ulama menilai kualitas tambahan tersebut berdasarkan kualitas perawinya, maka metode isnad cum matan menilai kualitas perawi berdasarkan riwayatnya.

Menarik untuk ditelusuri lebih lanjut adalah mengapa terjadi inkonsistensi dan dan atau pengabaian dalam penerapan uji kritik matan dalam proses kodifikasi hadis, seperti dinyatakan para tokoh di atas. Jika dikatakan bahwa pada saat itu belum tersusun kaedah keshahihan hadis yang baku dan sistematis, asumsi ini dapat diterima karena pembakuan kaedah tersebut baru terjadi pada abad ke-7 H. Namun ini bukan berarti para ulama penghimpun hadis-hadis ini tidak mempunyai standar atau acuan dalam menilai keshahihan hadis karena sejak periode shahabat aktivitas kritik matan yang

\footnotetext{
${ }^{6}$ Adanya keragaman redaksional matan hadis merupakan satu persoalan dalam kajian hadis dan disebut dengan periwayatan bil makna. Persoalan ini berangkat dari bagaimana menilai akurasi beragam redaksional matan sebuah hadis. Fenomena periwayatan seperti ini ditengarai telah ada sejak masa Nabi dan berlanjut hingga masa shahabat sehingga melahirkan sikap yang beragam. Sebagian tidak membolehkan, seperti Umar ibn al-Khathab, Abdullah ibn Umar dan Zaid ibn Arqam. Sementara shahabat lainnya, seperti Abdullah ibn Mas'ud, Anas ibn Malik, dan Umm al-Mukminin Aisyah, membolehkan periwayatan bil makna. Perbedaan pandangan ini terus terjadi pada masa tabi'in dan generasi sesudahnya hingga akhir periode kodifikasi (pembukuan) hadis. Setelah periode ini, ulama sepakat menyatakan bahwa periwayatan hadis harus secara lafzi dan melarang periwayatan secara makna. Muhammad 'Ajjaj al-Khatib, al-Sunnah Qabla al-Tadwin..., hal. 85, 89; M. Syuhudi Ismail, Kaedah Kesahihan Sanad..., hal. 71; Di era modern, perdebatan tentang periwayatan bil makna yang terjadi hingga tiga abad pertama tersebut kembali mencuat. Seperti Khaled Abou El Fadl yang menjadikan periwayatan bil makna sebagai bentuk kritik matan dalam menguji otentisitas dan otoritas hadis. Juga Kamaruddin Amin yang secara tersirat menyinggung persoalan ini dalam pernyataannya bahwa apabila sebuah hadis dapat dibuktikan berasal dari seorang shahabat, maka perlu pengujian lebih lanjut untuk mengetahui apakah kalimat atau isi hadis tersebut secara keseluruhan atau hanya sebahagian berasal dari Nabi. Khaled M Abou El-Fadl, Atas Nama Tuhan: Dari Fikih Otoriter ke Fikih Otoritatif, terj., (Jakarta: Serambi, 2004), hal. 31253; Kamaruddin Amin, Menguji Kembali Keakuratan..., hal. 53. Tentu saja, penelitian kedua tokoh ini mengarah kepada keabsahan periwayatan bil makna pada sebagai metode periwayatan hadis karena tidak mustahil periwayatan ini menyebabkan adanya 'tambahan atau perubahan' pada hadis-hadis Nabi, atau bahkan tidak mustahil telah membuka peluang masuknya hadis-hadis palsu ke dalam ajaran Islam. Khaled M Abou El-Fadl, Atas Nama Tuhan: Dari Fikih Otoriter ke Fikih Otoritatif, terj., (Jakarta: Serambi, 2004), hal. 31253; Kamaruddin Amin, Menguji Kembali Keakuratan..., hal. 53
} 
mereka lakukan menunjukkan dinamisasi praktek kritik tersebut. Disinilah Imam al-Syafi'i sebagai peletak dasar teorisasi keilmuan hadis mempunyai peran penting dalam proses kodifikasi tersebut.

Agaknya, analisis yang diberikan oleh Amin Abdullah (1996: 201-206) dapat dipakai untuk menjelaskan fenomena ini. Menurutnya, abad kedua merupakan awal dari proses pembakuan hadis, sebagai bahagian dari proses pembakuan ajaran Islam atau disebut juga dengan ortodoksi. Dalam hal ini Imam al-Syafi'i menjadi tokoh sentral selama proses ortodoksi tersebut. Beliau merupakan sosok ulama yang menerima dan membela hadis mengenai hukum dalam skala massal sebagai suatu dasar hukum dengan memposisikan hadis sebagai sumber ajaran bersama dengan al-Qur'an. Pandangan Imam al-Syafi'i inilah yang kemudian disebarluaskan oleh murid-muridnya, termasuk Imam Ahmad ibn Hanbal. Melalui Imam Ahmad juga teori keilmuan hadis Imam al-Syafi'i kemudian mengkristal dan diterima oleh para penulis kitab-kitab hadis mu'tabar, seperti Imam al-Bukhari dan Imam Muslim yang notabene merupakan murid-murid Imam Ahmad. Teori inilah yang kemudian menjadi standar umum dalam proses seleksi pembukuan hadis. ${ }^{7}$

Hanya saja, seperti dijelaskan lebih lanjut oleh Amin Abdullah (1996: 207-208), harus dimaklumi mengapa Imam al-Syafi'i menghasilkan pemikiran-pemikiran tersebut. Hal ini dikarenakan untuk mengantisipasi perkembangan dan pemekaran pemikiran politik, hukum dan kalam saat itu hingga ia merasa perlu menyusun pokok-pokok ajaran Islam yang standar dan seragam, yang dapat dijadikan pedoman oleh umat Islam saat itu dan generasi berikutnya. Untuk menjaga integrasi kaum muslimin yang secara keseluruhan saat itu sudah terpecah-pecah menjadi khawarij, Murji'ah, Jahmiyah dan lain sebagainya maka langkah Imam al-Syafi'i untuk menyatukan umat dengan bersandar pada otoritas hadis memang sangat diperlukan. Apalagi kemudian kekisruhan ini diikuti dengan munculnya hadis-hadis palsu sebagai ekses dari pertentangan tersebut. Karena itu, demi untuk menyelamatkan masa-masa kritis periode perumusan ortodoksi, langkah semua ulama terdahulu ini tidak bisa tidak dilakukan. Dengan plus minusnya, langkah para ahli hadis ini tidak bisa dihindari. Dalam tempo yang relatif singkat, ajaran ortodoksi ini kemudian mengkristal sedemikian rupa sehingga orang yang datang belakangan tinggal membuka rumusan dan periwayatan mereka lewat al-kutub al-sittah. Para ulama di belakang hari lebih suka menerima hadis sebagai apa adanya,

${ }^{7}$ Imam al-Syafi'i secara tegas menyatakan bahwa syarat diterimanya sebuah hadis ahad (khabar khashah) sebagai hujjah adalah sebagai berikut: (1) Perawi hadis tersebut harus seorang yang tsiqah, (2) Ia dikenal jujur dalam periwayatannya, (3) Mengetahui dan memahami setiap periwayatan yang disampaikannya, (4) Mengetahui hal-hal yang dapat mengubah makna redaksional hadis, (5) Jika si perawi adalah orang yang tidak mengetahui tentang perubahan makna, maka ia harus meriwayatkan hadis secara lafzi karena dikhawatirkan jika ia meriwayatkan hadis secara makna akan terjadi perubahan makna hadis tersebut, (6) Perawi harus hafiz; memiliki daya ingat terhadap setiap yang ia riwayatkan; baik yang didasarkan atas ingatan ataupun catatan hadisnya, (7) Riwayatnya harus sesuai dengan periwayatan ulama tsiqah lainnya jika mereka juga meriwayatkan hadis yang sama, (8) Perawi tersebut bukan seorang mudallis. Persyaratan ini berlaku untuk semua perawi pada sebuah jalur sanad, mulai dari perawi pertama hingga 
seperti tertulis dalam kitab-kitab tersebut. Hadis yang terumuskan dari sunnah yang hidup saat itu mempunyai harga mati yang tidak dapat ditawar-tawar lagi. Pada gilirannya orang sulit membedakan mana hadis yang bersifat mutlak, yang terbebas dari ikatan ruanga dan waktu, dengan hadis yang bersifat nisbi, yang terikat dengan ruang dan waktu. Padahal seiring dengan perubahan masyarakat dengan berbagai tantangannya masing-masing, proses ortodoksi dan proses dinamisasi (pencairan ajaran) harus berjalan bersama-sama.

\section{E. Kesimpulan}

Dari paparan di atas diketahui bahwa para ulama telah merumuskan kaedah keshahihan hadis yang kemudian disepakati sebagai 'batu uji’ otentisitas penisbahan hadis kepada Rasulullah saw. Bagi beberapa pemikir muslim modern, kaedah keshahihan hadis ini - jika dianalisis dari aspek epistemologi - memiliki kelemahan sebagai sebuah ilmu. Kelemahan tersebut berupa penerimaan kebenaran otoritas sebagai uji validitas sanad dan adanya inkonsistensi dalam uji validitas matan. Menurut mereka, otoritas atau kesaksian memiliki tingkat kebenaran yang rendah karena itu berpengaruh terhadap kebenaran informasi yang diterima. Sementara inkonsistensi dalam kritik matan karena lebih mengutamakan uji kritik terhadap format susunan matan, seperti matan terbalik (maqlub), mendapat sisipan (idrak) atau mendapat tambahan (ziyadah). Ini berakibat pada munculnya hadis-hadis yang bermasalah jika dilakukan tela'ah ulang, sekalipun terdapat dalam kitab-kitab hadis mu'tabar.

Untuk menutupi kelemahan epistemologi ini, para pemikir muslim modern mulai mengembangkan metode uji kritik hadis baik berupa rekonstruksi uji kritik matan dan atau kepada penggabungan kritik sanad dan matan secara proporsional dan berimbang dengan menjadikan kedua kritik ini pada posisi yang independen, sejajar dan saling melengkapi. Terkait dengan kritik sanad, sekalipun menurut keilmuan sejarah kutub al-rijal, kutub al-thabaqat, dan kutub al-jarh wa al-ta'dil ditulis jauh setelah peristiwa sejarahnya terjadi, namun informasi tersebut tidak harus diabaikan sama sekali mengingat pada kitab-kitab tersebut masih tersimpan aspek-aspek historis (historical kernel). Sikap kritis inilah yang mereka munculkan dengan menyusun kriteria dan metode baru uji kritik hadis. Karena itu, terlepas dari reaksi pro - kontra yang muncul, kajian akademik ini harus diapresiasi mengingat sebagai sebuah kajian ilmiah, ilmu hadis harus terus berbenah agar dapat menyesuaikan diri dengan tuntutan perkembangan sains modern sehingga hadis yang menjadi objek keilmuannya dapat semakin dibuktikan otentisitasnya.

terakhir. Muhammad ibn Idris al-Syafi'i, Al-Risalah, Pen-tahqiq AhmadMuhammad Syakir, (Beirut: Dar al-Kutub al'Ilmiyyah, t.th), hal. 370-372 


\section{Daftar Pustaka}

A. Sony Keraf dan Mikhael Dua, Ilmu Pengetahuan Sebuah Tinjauan Filosofis, Yogyakarta: Kanisius, 2001

Abdul Fatah Idris, Hadis-Hadis Prediktif dan Teknis: Studi Pemikiran Fazlur Rahman, Semarang: Pustaka Rizki Putra, 2012

Abu 'Amr Usman ibn Abdurrahman ibn al-Shalah al-Syahrazuriy, Ulum al-Hadis li Ibn al-Shalah, Damaskus: Dar al-Fikr, 1984

Aksin Wijaya, Satu Islam Ragam Epistemologi: Dari Teologi Teosentrisme ke Antroposentrisme, Yogyakarta: Pustaka Pelajar, 2014

Amin Abdullah, 'Al-Ta'wil al-'Ilmi: Ke Arah Perubahan Paradigma Penafsiran Kitab Suci, dalam Al-Jami'ah: Journal of Islamic Studies, Vol. 39, Number 2, July - December 2001

Amin Abdullah, "Hadis dalam Khazanah Intelektual Muslim: Al-Ghazali dan Ibn Taymiyah (Tinjauan Implikasi dan Konsekuensi Pemikiran)", dalam Yunahar Ilyas dan M. Mas'udi, Perkembangan Pemikiran Terhadap Hadis, Yogyakarta: LPPI Univ. Muhammadiyah, 1996

Amsal Bakhtiar, Filsafat Ilmu, Jakarta: RajaGrafindo Persada, 2006

Aunur Rofiq Ma'ruf, "Muhammad al-Ghazali dan Gerakan Reformasi Pasca Muhammad Abduh: Dari Pembaruan Fiqh Hingga Feminisme", dalam M. Aunul Abied Shah (ed.), Islam Garda Depan: Mosaik Pemikiran Islam Timur Tengah, Bandung: Mizan, 2001

Departemen Pendidikan dan Kebudayaan, Kamus Umum Bahasa Indonesia, (Jakarta: Balai Pustaka, 1988), hal. 466

Faiqotul Mala, Otoritas Hadis-Hadis Bermasalah dalam Shahih Al-Bukhari, Jakarta: Elex Media Komputindo, 2015

Harold H. Titus et al., Persoalan-Persoalan Filsafat, diterjemahkan oleh M. Rasjidi, Jakarta: Bulan Bintang, 1984

Hasjim Abbas, Kritik Matan Hadis Versi Fuqaha dan Muhaddisin, Yogyakarta: Teras, 2004

Idzam Fautanu, Filsafat Ilmu: Teori dan Aplikasi, Jakarta: Referensi, 2012

Ilyas Supena dan M. Fauzi, Dekonstruksi dan Rekonstruksi Hukum Islam, Yogyakarta: Gaya Media, 2001

'Imaduddin Muhammad Rasyid, Nazhariyat Naqd al-Rijal wa Makaanatuha fi Dhaw'i al-Bahts al'Ilmiy, Riyadh: Muassasah al-Risalah, t.th.

Imam Syaukani, Rekonstruksi Epistemologi Hukum Islam Indonesia dan Relevansinya Bagi Pembangunan Hukum Nasional, Jakarta: RajaGrafindo Persada, 2006

Jujun S. Suriasumantri, Filsafat Ilmu Sebuah Pengantar Populer, Jakarta: Pustaka Sinar Harapan, 2007

Kamaruddin Amin, Menguji Kembali Keakuratan Metode kritik Hadis, Bandung: Hikmah, 2009

Louis O. Kattsof, Pengantar Filsafat, terj. Soerjono Soemargono, Yogyakarta: Tiara Wacana, 1989

M. Syuhudi Ismail, Kaedah Keshahihan Sanad Hadis Telaah Kritis dan Tinjauan dengan Pendekatan Ilmu Sejarah, Jakarta: Bulan Bintang, 1990 
M. Syuhudi Ismail, Metodologi Penelitian Hadis Nabi, Jakarta: Bulan Bintang, 1992

M.M. A'zhami, Manhaj al-Naqd 'inda al-Muhaddisin Nasy`atuhu wa Tarikhuhu, (Saudi Arabia: Maktabah al-Kawsar, 1990

Mahmud Thahhan, Ushul al-Takhrij wa Dirasat al-Asanid, Maktabah al-Ma'arif, 1996

Mahmud Thahir al-Jawwabi, Al-Jarh wa Al-Ta'dil Bayn al-Mutasyaddidin wa al-Mutasahilin, t.tp: Al-Dar al-'Arabiyah li al-Kitabah, 1997

Muhammad ‘Ajjaj al-Khatib, al-Sunnah Qabla al-Tadwin, Beirut: Dar al-Fikr, 2001

Muhammad 'Ajjaj al-Khatib, Ushul al-Hadis: 'Ulumuhu wa Mushthalahuhu, Beirut: Dar al-Fikr, 1989

Muhammad Ali Qasim al-'Umariy, Dirasat fi Manhaj al-Naqd 'inda al-Muhaddisin, Yordan: Dar alNafa' is, t.th

Muhammad ibn Idris al-Syafi'i, Al-Risalah, Pen-tahqiq AhmadMuhammad Syakir, Beirut: Dar alKutub al-'Ilmiyyah, t.th

Muhyar Fanani, Fiqh Madani: Konstruksi Hukum Islam di Dunia Modern, Yogyakarta: LKis, 2010

Muhyar Fanani, Ilmu Ushul Fiqh di Mata Filsafat Ilmu, Semarang: Walisongo Press, 2009

Mujamil Qomar, Epistemologi Pendidikan Islam: Dari Metode Rasional hingga Metode Kritik, Jakarta: Erlangga, 2007

Mun'im A. Sirry, Kontroversi Islam Awal Antara Mazhab Tradisionalis dan Revisionis, Bandung: Mizan 2015

Musfir Abdullah al-Damini, Maqayis Naqd Mutun al-Sunnah, Riyadh: Jami'ah Ibn Sa'ud, 1984), hal. 49

Muslim ibn Hajjaj, Muqaddimah Shahih Muslim, Riyadh: Bayt al-Afkar al-Dawliyah, 1998

Nuruddin 'Itr, Manhaj al-Naqd fi 'Ulum al-Hadis, Damaskus: Dar al-Fikr, 1988

Saifuddin Zuhri Qudsy, Living Hadis: Genealogi, Teori, dan Aplikasi, Jurnal Living Hadis, Volume 1, Nomor 1, Mei 2016

Shalahuddin ibn Ahmad al-Idhibiy, Manhaj Naqd Matn 'inda Ulama' al-Hadis al-Nabawi, Beirut: Dar al-Afaq al-Jadidah, 1983

Syamsul Anwar, Interkoneksi Studi Hadis dan Astronomi, Suara Muhammadiyah: Yogyakarta, 2011

Tim Dosen Filsafat Ilmu Fakultas Filsafat UGM, Filsafat Ilmu Sebagai Dasar Pengembangan Pengetahuan, Yogyakarta: Liberty, 2007

Zaprulkhan, Filsafat Ilmu: Sebuah Analisis Kontemporer, Jakarta: RajaGrafindo Persada, 2016 http://kbbi.web.id/kritik, diakses tgl 10 Juni 2017 